\title{
PENDIDIKAN IPS DALAM MEMBENTUK SDM BERADAB
}

\author{
Asep Eri Ridwan, Prodi Pendidikan IPS, SPs, UPI.
}

\begin{abstract}
ABSTRAK
Pendidikan merupakan hal yang sangat penting dalam kehidupan manusia, oleh karena itu harus mendapat perhatian yang lebih serius. Berkaitan dengan hal ini, pendidikan merupakan suatu sistem untuk meningkatkan kualitas hidup manusia dalam segala aspek kehidupan, sekaligus sebagai upaya pewarisan nilai-nilai budaya bagi kehidupan manusia. Pendidikan IPS merupakan bagian integral dari sistem pendidikan nasional yang bertujuan untuk membangun warga negara yang baik. Melalui Pendidikan IPS diharapkan terbentuk Sumberdaya Manusia (SDM) yang beradab, yakni SDM yang berpendidikan (berpengetahuan dan berketerampilan) dan berbudaya (berkarakter kuat).
\end{abstract}

Kata kunci: pendidikan IPS, sumberdaya manusia beradab.

\section{PENDAHULUAN}

Pendidikan merupakan salah satu hal yang sangat penting dalam kehidupan manusia. Melalui pendidikan, manusia bisa mengembangkan kehidupannya ke taraf yang lebih baik. Sejalan dengan pendapat Somantri (2001: 55), yang menyatakan bahwa begitu pentingnya, peran pendidikan sering dianggap sebagai "kekuatan". Socrates misalnya beranggapan bahwa pengetahuan adalah kekuatan (knowledge is power). Negara-negara yang mengagungkan kredo keilmuan pun pada saat ini menempatkan pendidikan pada nilai sentral pembangunannya. Lebih lanjut Somantri (2001: 56), menegaskan bahwa education as power yang bisa meningkatkan kualitas hidup, bahkan sebagai director of power. Pendidikan merupakan pembangkit dan director of power terhadap kekuatan lainnya yang sudah diperoleh manusia seperti kekuatan politik, ekonomi, pertahanan. Sedangkan Brownhill dan Smart (1989: 2), menyebut pendidikan sebagai sebuah alat kontrol sosial.

Pendidikan sering juga disebut sebagai suatu proses untuk memanusiakan manusia. Dalam hal ini, seorang bayi yang lahir tidak akan begitu saja menjadi manusia yang berbudaya, karena menjadi manusia yang berbudaya harus melalui pengisian jasmani dan rohani (nurture). Proses nurture merupakan transfer dari berbagai bentuk karya, rasa dan karsa dari budaya, di mana proses pendidikan itu terjadi. Dimensi ini merupakan dasar dari kelanjutan hidup dan budaya suatu masyarakat. Tanpa dimensi transfer ini suatu kebudayaan akan musnah. Transfer budaya dari generasi ke generasi terjadi dalam proses pendidikan (Tilaar dan Sutaryadi, 1994: 189).

Para ahli antropologi pendidikan, seperti Teodore Brameld, melihat keterkaitan yang sangat erat antara pendidikan dengan kebudayaan. Keduanya merupakan satu kesatuan yang tidak dapat dipisahkan, sebab pendidikan tidak terlepas dari kebudayaan dan pendidikan hanya dapat terlaksana dalam suatu masyarakat yang berbudaya. Merujuk pada Tilaar dan Sutaryadi (1994: 190-192), terdapat tiga fungsi pendidikan dalam kaitannya dengan upaya menjaga kesinambungan kebudayaan dan sebagai agen pengembangan kebudayaan, yakni: (1) fungsi preservasi dinamik dari seluruh lembaga pendidikan; (2) fungsi partisipatoris; dan (3) fungsi prepatoris antisipatoris yang dikaitkan dengan masyarakat industri masa depan.

Fungsi preversi dinamik kebudayaan, artinya pendidikan merupakan reservator budaya. Dalam kaitan ini pendidikan berfungsi untuk mempertahannkan unsur-unsur esensial dari kebudayaan dan membuka diri terhadap unsur-unsur positif dari luar. Tugas pendidikan adalah menanamkan aspirasi budaya melalui penghayatan budaya yang fungsional sekaligus mengembangkan daya kreativitas peserta didik 
dalam melestarikan dan mengembangkan kebudayaannya.

Fungsi partisipatoris kebudayaan adalah fungsi pendidikan merupakan proses untuk secara aktif menggodok nilai-nilai budaya lama dengan nilai-nilai kontemporer, sehingga terbentuk kepribadian manusia yang sejalan dengan keperluan masa kini dan masa mendatang. Proses peramuan nilai budaya itu menunjukan betapa kebudayaan dan pendidikan merupakan dua unsur yang saling mengikat. Kebudayaan itu hidup dan berkembang karena proses pendidikan dan proses pendidikan itu sendiri hanya ada dalam suatu konteks kebudayaan.

Fungsi preparatoris antisipatoris kebudayaan maksudnya pendidikan harus dapat mempersiapkan generasi muda dengan membekali berbagai kemampuan dan tingkah laku yang sesuai dengan nilai-nilai budaya dan mampu mengantisipasi perkembangan perubahan global yang dapat membentuk manusia berbudaya. Proses pendidikan merupakan wahana yang sangat penting dalam membangun kebudayaan sejalan dengan perkembangan era globalisasi.

\section{PEMBAHASAN}

Seperti telah diketahui bahwa dewasa ini kemajuan teknologi dan informasi telah jauh mengubah tatanan kehidupan dunia dengan menciptakan sebuah konsep yang disebut globalisasi. Globalisasi telah membuat sekat antar negara menjadi tidak tampak lagi, sehingga dunia seakan ada dalam sebuah genggaman. Dalam dunia pendidikan diperlukan perubahan yang mampu untuk mengatasi permasalahan akibat dari globalisasi ini. Merujuk pada Griffin, P., Care, E., \& McGaw, B. (2012: 1-2), bahwa terdapat peningkatan kesadaran dari banyak negara yang berpindah dari negara industri menjadi negara yang ekonominya berdasarkan pada informasi, dan sistem-sistem pendidikan harus merespon pada perubahan ini. Pendidikan menghadapi suatu tantangan baru, yakni untuk memberikan kepada rakyat suatu keterampilan informasi yang diperlukan dalam masyarakat informasi. Sistem pendidikan harus menyesuaikan, mene- kankan informasi dan keterampilan teknologi, bukan berbasis pada produksi.

Perubahan mendasar dalam beberapa dekade terakhir ini telah menuntut perubahan pada peran pembelajaran dan pendidikan seharihari. Trilling dan Fadel (2009: 6), menyatakan bahwa salah satu peran utama pendidikan adalah untuk mempersiapkan pekerja masa depan dan warga negara untuk menghadapi tantangan jaman mereka. Pengetahuan kerja jenis pekerjaan yang kebanyakan orang akan perlu dalam dekade mendatang - bisa dilakukan dimana saja oleh siapa saja yang memiliki keahlian, ponsel, laptop, dan koneksi internet. Namun untuk memiliki pekerja berpengetahuan ahli, setiap negara membutuhkan sistem pendidikan yang menghasilkan mereka; karena itu, pendidikan menjadi kunci untuk kelangsungan hidup ekonomi di abad 21.

Pendidikan dan pembelajaran yang dijalankan pada saat ini tentu saja harus mampu merespon dengan baik pada perubahan yang terjadi. Pendidikan dan pembelajaran tidak lagi hanya bertugas untuk mentransfer ilmu pengetahuan yang dibutuhkan untuk pekerjaanpekerjaan manual dan rutin, melainkan harus mampu membelajarkan peserta didik agar memiliki kemampuan dan keterampilan yang bisa digunakan untuk hidup dan menghadapi persaingan yang begitu ketat di abad ke-21 ini. Berkaitan dengan hal ini, pembelajaran seharusnya sudah mampu memberikan kemampuan dasar dan keterampilan terapan yang sangat berguna bagi peserta didik dalam menjalani kehidupan dan memperoleh pekerjaan. Kemampuan yang dimaksud oleh Trilling dan Fadel (2009:7), dirinci sebagai berikut : komunikasi lisan dan tertulis; berpikir kritis dan pemecahan masalah; profesionalisme dan etos kerja; kerja tim dan kolaborasi; bekerja dalam tim beragam; menerapkan teknologi; serta kepemimpinan dan manajemen proyek.

Selanjutnya, dengan berkembangnya atau berubahnya masyarakat yang begitu cepat pada abad informasi atau abad ke-21 ini, menuntut pembelajar harus menguasai beberapa keterampilan seperti dinyatakan oleh Trilling dan Fadel (2009: 49) antara lain Critical thinking and problem solving (expert thinking); Communication and collaboration (complex 
communicating); dan Creativity and innovation (applied imagination and invention). Lebih jauh lagi mereka menyatakan bahwa di dalam dunia yang sudah mengglobal ini pembelajar wajib menguasai Information, media, and technology skills. Semua keterampilan tersebut diharapkan didapatkan oleh peserta didik melalui proses pembelajaran di sekolah.

Proses pembelajaran di sekolah merupakan salah satu unsur dari dunia pendidikan. Pendidikan merupakan hak asasi setiap warga negara Indonesia, dan untuk itu setiap warga negara Indonesia berhak memperoleh pendidikan yang bermutu sesuai dengan minat dan bakat yang dimilikinya tanpa memandang status sosial ekonomi, suku, etnis, agama, dan gender. Pemerataan akses dan peningkatan mutu pendidikan akan membuat warga negara Indonesia memiliki kecakapan hidup (life skills) sehingga mendorong tegaknya pembangunan manusia seutuhnya serta masyarakat madani dan modern yang dijiwai nilai-nilai Pancasila, sebagaimana telah diamanatkan dalam UU No 20 Tahun 2003 tentang Sistem Pendidikan Nasional. Dalam UU No 20 Tahun 2003 tentang Sistem Pendidikan Nasional, pendidikan didefinisikan sebagai usaha sadar dan terencana untuk mewujudkan suasana belajar dan proses pembelajaran agar peserta didik secara aktif mengembangkan potensi dirinya untuk memiliki kekuatan spiritual keagamaan, pengendalian diri, kepribadian, kecerdasan, akhlak mulia, serta keterampilan yang diperlukan dirinya, masyarakat, bangsa dan negara

Pendidikan Ilmu Pengetahuan Sosial (PIPS) merupakan bagian integral dari sistem pendidikan nasional. PIPS merupakan padanan dari social studies education dalam konteks kurikulum di Amerika Serikat. Pada dasarnya PIPS merupakan studi integratif dari ilmu-ilmu sosial (sosiologi, ekonomi, sejarah, geografi, antropologi, dan lain-lain), dan humaniora (agama, bahasa, dan lain-lain) yang disederhanakan dan ditujukan untuk kepentingan pendidikan. Hal ini sejalan dengan apa yang dinyatakan oleh Somantri (2001:74), bahwa Pendidikan IPS adalah suatu penyederhanaan disiplin ilmu-ilmu sosial, ideologi negara dan disiplin ilmu lainnya serta masalah-masalah sosial terkait, yang diorganisasikan dan disajikan secara ilmiah dan psikologis untuk tujuan pendidikan pada tingkat pendidikan dasar dan menengah.

Hakekat PIPS tersebut mengacu juga pada apa yang dinyatakan oleh National Council For the Social Studies (1994: 3), yang memberikan definisi IPS atau social studies sebagai berikut:

"...the integrated study of the social sciences and humanities to promote civic competence. Within the school program, social studies provides coordinated, systematic study drawing upon such disciplines as anthropology, archaeology, economics, geography, history, law, philosophy, political science, psychology, religion, and sociology, as well as appropriate content from the humanities, mathematics, and natural sciences. The primary purpose of social studies is to help young people make informed and reasoned decisions for the public good as citizens of a culturally diverse, democratic society in an interdependent world."

Merujuk pada Permendiknas No 22 Tahun 2006 tentang Standar Isi Mata Pelajaran disebutkan bahwa mata pelajaran IPS bertujuan agar peserta didik memiliki kemampuan sebagai berikut: (1) mengenal konsep-konsep yang berkaitan dengan kehidupan masyarakat dan lingkungannya; (2) memiliki kemampuan dasar untuk berpikir logis dan kritis, rasa ingin tahu, inkuiri, memecahkan masalah, dan keterampilan dalam kehidupan sosial; (3) memiliki komitmen dan kesadaran terhadap nilai-nilai sosial dan kemanusiaan; dan (4) memiliki kemampuan berkomunikasi, bekerjasama dan berkompetisi dalam masyarakat yang majemuk, di tingkat lokal, nasional, dan global.

Sejalan dengan pandangan Sumaatmadja (2001: 20), bahwa mata pelajaran IPS bertujuan mengembangkan potensi peserta didik agar peka terhadap masalah sosial yang terjadi di masyarakat, memiliki sikap mental positif terhadap perbaikan segala ketimpangan yang terjadi, dan terampil mengatasi setiap masalah yang terjadi sehari-hari baik yang menimpa dirinya maupun yang menimpa kehidupan masyarakat. Sedangkan Sapriya (2009: 51), menyatakan bahwa Pendidikan IPS sangat memperhatikan dimensi keterampilan di 
samping pemahaman dalam dimensi pengetahuan. Kecakapan mengolah dan menerapkan informasi merupakan keterampilan yang sangat penting untuk mempersiapkan siswa menjadi warga negara yang mampu berpartisipasi secara cerdas dalam masyarakat demokrasi.

Mutakin (1998), memberikan rumusan tujuan dari IPS secara lebih rinci, yang dapat diuraikan sebagai berikut:

a. Memiliki kesadaran dan kepedulian terhadap masyarakat atau lingkungannya, melalui pemahaman terhadap nilai-nilai sejarah dan kebudayaan masyarakat.

b. Mengetahui dan memahami konsep dasar dan mampu menggunakan metode yang diadaptasi dari ilmu-ilmu sosial yang kemudian dapat digunakan untuk memecahkan masalah-masalah sosial.

c. Mampu menggunakan model-model dan proses berpikir serta membuat keputusan untuk menyelesaikan isu dan masalah yang berkembang di masyarakat.

d. Menaruh perhatian terhadap isu-isu dan masalah-masalah sosial, serta mampu membuat analisis yang kritis, selanjutnya mampu mengambil tindakan yang tepat.

e. Mampu mengembangkan berbagai potensi sehingga mampu membangun diri sendiri agar survive yang kemudian bertanggung jawab membangun masyarakat.

Lebih lanjut dijelaskan Maftuh (2010), bahwa jika kita mengkaji berbagai pendapat dari para ahli IPS (social studies) dalam buku-buku klasik mereka, seperti Banks (1990:3), Jarolimek (1986:4), Michaelis (1988:2), Ross 17 (1997:6), Savage dan Armstrong (1987:6), dan Woolever \& Scot (1988) tentang tujuan IPS (social studies), maka terdapat suatu pandangan yang sejalan bahwa tujuan utama IPS (social studies) adalah untuk memajukan kemampuan warga negara untuk berpartisipasi dalam masyarakat demokratis. Dengan kata lain, IPS (social studies) ditujukan untuk mempersiapkan peserta didik menjadi warga negara yang baik yang memiliki pengetahuan, nilai, dan keterampilan yang diperlukan untuk berpartisipasi secara aktif di masyarakat.National Council for the Social Studies (1994:3) mempertegas pula bahwa tujuan utama social studies adalah untuk: "... help young people develop the ability to make informed and reasoned decisions for the public good as citizens of a culturally diverse, democratic society in an interdependent world."

Agar tujuan-tujuan tersebut di atas dapat tercapai, maka perlu dikembangkan sejumlah kemampuan yang dibelajarkan melalui mata pelajaran IPS. Merujuk pada Banks (1990:6), terdapat sejumlah kemampuan yang perlu dimiliki peserta didik melalui IPS yang meliputi: (a) pengetahuan, (b) keterampilan, (c) sikap dan nilai, dan (d) praktik warga negara. Peserta didik perlu menguasai pengetahuan dalam upaya membuat keputusan reflektif dan untuk berpartisipasi secara efektif dalam komunitas warganegara. Peserta didik perlu memiliki keterampilan yang meliputi keterampilan berpikir, keterampilan penelitian ilmu sosial, keterampilan akademik dan keterampilan kelompok (group skills). Peserta didik sebagai warga negara juga perlu mengembangkan komitmen terhadap nilai-nilai demokratis dan kemanusiaan (democratic and human values), seperti harkat martabat dan kesederajatan manusia, dalam upaya untuk membuat keputusan reflektif dan untuk mengambil tindakan yang konsisten dengan nilai-nilai idealis negara. Melalui IPS peserta didik juga perlu diberi kesempatan untuk berpartisipasi dalam kegiatan-kegiatan yang akan mengembangkan pengetahuan yang lebih luas tentang kehidupan politik dan mengajarkan keterampilan yang berguna dalam mempengaruhi lembaga-lembaga sosial dan warga negara.

Maftuh (2010), secara khusus menyoroti beberapa keterampilan abad ke-21 di mana Pendidikan IPS dapat memainkan peranan pentingnya, yakni pada kelompok keterampilan sosial yang meliputi: keterampilan interpersonal, keterampilan bekerja sama (kolaborasi) lintas jaringan, keterampilan interaksi sosial dan lintas budaya, tanggung jawab personal dan sosial, komunikasi interaktif, literasi budaya, dan kesadaran global. Selain tentang keterampilan sosial, Maftuh (2010), juga menyoroti tentang kaitan Pendidikan IPS dengan masalah-masalah sosial yang sering terjadi di Indonesia, dalam hal ini tentang pendidikan resolusi konflik. 
Menurutnya, pengembangan pendidikan resolusi konflik di sekolah berkaitan dengan tanggung jawab sekolah dalam menyiapkan siswa menjadi warga negara yang demokratis dan bertanggung jawab. Warga negara yang demokratis dan bertanggung jawab mesti mampu mengatasi dan menyelesaikan konflik mereka sendiri dalam cara-cara yang demokratis dan konstruktif, bukan melalui tindakan kekerasan.

Jika mencermati hakikat dan tujuan dari Pendidikan IPS tersebut di atas, maka dapat dikatakan bahwa Pendidikan IPS sangat berkaitan erat dengan pendidikan karakter. Sebagaimana merujuk pada Zuchdi (2008: 5), bahwa pendidikan karakter dapat dimaknai sebagai pendidikan nilai, pendidikan moral atau pendidikan budi pekerti. Pemaknaan tersebut memiliki arah dan tujuan yang sama dengan tujuan pendidikan IPS, yakni membangun warga negara yang baik. Berkaitan dengan hal tersebut, sudah sejak beberapa tahun terakhir pemerintah sebenarnya telah menerapkan pendidikan yang berbasis pada pembentukan karakter atau lebih dikenal dengan sebutan pendidikan karakter.

Pendidikan karakter adalah pendidikan yang bukan hanya mengajarkan mana yang benar dan salah. Lebih dari itu, pendidikan karakter adalah usaha menanamkan kebiasaankebiasaan yang baik (habituation) sehingga peserta didik mampu bersikap dan bertindak berdasarkan nilai-nilai yang telah menjadi kepribadiannya. Melalui pendidikan karakter, peserta didik menjadi paham (domain kognitif) tentang mana yang baik dan salah, mampu merasakan (domain afektif) nilai yang baik dan biasa melakukannya (domain perilaku). Jadi, pendidikan karakter terkait erat dengan "habit" atau kebiasaan yang terus menerus dipraktekan atau dilakukan. Pendidikan karakter yang baik harus melibatkan pengetahuan yang baik (moral knowing), perasaan yang baik atau loving good (moral feeling) dan perilaku yang baik (moral action) sehingga terbentuk perwujudan kesatuan perilaku dan sikap hidup peserta didik (Balitbang Pusat Kurikulum dan Perbukuan, 2011: 7).

Konsep karakter sendiri memiliki banyak pengertian. Merujuk pada McKinnon (1999: 57-
58), karakter memiliki banyak arti secara kamus maupun bahasa sehari-hari. Arti pertama adalah naturalistik; secara sederhana merupakan suatu bagian dari sifat manusia untuk membentuk karakter, untuk mengembangkan diri. Sebagaimana wajar bagi manusia untuk tumbuh secara fisik, maka wajar bagi manusia untuk membentuk diri dengan memperoleh sifat-sifat yang dianggap layak dan berguna, yang memberikan mereka alasan untuk bertindak. Arti kedua menekankan pada aspek etis; kita menilai orang memiliki karakter baik atau buruk merujuk pada apakah kita berpikir mereka memiliki atau tidak memiliki sifat-sifat yang membuat mereka hidup yang layak dipuji secara etis dan/atau yang meningkatkan kehidupan orang-orang di sekitar mereka. Arti ketiga lebih metafisik; karakter berfungsi untuk membedakan orang, memberikan kriteria identitas. Hal ini membuat setiap orang adalah dirinya sendiri, bukan orang lain. Dua orang bisa memiliki karakter yang mirip, tapi tidak dapat memiliki karakter yang sama.

Kurikulum sebagai integrator sistem nilai, pengetahuan dan keterampilan, harus mampu membentuk karakter peserta didik seperti tercantum dalam tujuan pendidikan nasional itu sendiri. Berkaitan dengan hal tersebut, pendidikan karakter bertujuan mengembangkan nilai-nilai yang membentuk karakter bangsa yaitu Pancasila, yang meliputi mengembangkan potensi peserta didik agar menjadi manusia berhati baik, berpikiran baik, dan berperilaku baik; membangun bangsa yang berkarakter Pancasila; mengembangkan potensi warga negara agar memiliki sikap percaya diri, bangga pada bangsa dan negaranya serta mencintai umat manusia. Pendidikan karakter berfungsi membangun kehidupan kebangsaan yang multikultural; membangun peradaban bangsa yang cerdas, berbudaya luhur, dan mampu berkontribusi terhadap pengembangan kehidupan umat manusia; mengembangkan potensi dasar agar berhati baik, berpikiran baik, dan berperilaku baik serta keteladanan baik; membangun sikap warga negara yang cinta damai, kreatif, mandiri, dan mampu hidup berdampingan dengan bangsa lain dalam suatu harmoni (Balitbang Pusat Kurikulum dan Perbukuan, 2011: 8). 
Selain itu, empat pilar kebangsaan, yakni Pancasila, Undang-Undang Dasar Negara Republik Indonesia Tahun 1945, Negara Kesatuan Republik Indonesia dan Bhinneka Tunggal Ika memberikan landasan filosofis serta berbagai prinsip dasar dalam pembangunan pendidikan dan kebudayaan. Landasan filosofis tersebut, menempatkan manusia Indonesia sebagai makhluk yang diciptakan oleh Tuhan Yang Maha Esa dengan segala fitrahnya dengan tugas memimpin kehidupan yang berharkat dan bermartabat serta menjadi manusia yang bermoral, jujur, berbudi luhur, berakhlak mulia, mempunyai karakter dan jati diri bangsa, serta menghargai keragaman budaya (Kementrian Pendidikan dan Kebudayaan, 2010: 4).

Merujuk pada Kementrian Pendidikan dan Kebudayaan (2010:8), penyelenggaraan pendidikan dan kebudayaan didasarkan pada beberapa paradigma universal yang perlu diperhatikan sebagai berikut: (a) pemberdayaan manusia seutuhnya; (b) pengembangan konvergensi peradaban; (c) pembelajaran sepanjang hayat berpusat pada peserta didik; (d) pendidikan untuk semua; (e) pendidikan untuk perkembangan, pengembangan, dan/atau pembangunan berkelanjutan (PuP3B); (f) pelestarian dan pengelolaan kebudayaan Indonesia.

Kurikulum sebagai panduan pelaksanaan kegiatan pembelajaran harus disusun sedemikian rupa, agar mendukung dan mengembangkan pengetahuan, sikap, dan keterampilan siswa, harus mampu membentuk watak atau karakter siswa. Setidaknya ada lima prinsip pengembangan kurikulum menurut Asep Herry Hernawan dkk (2002), seperti dikutip dalam Sudrajat (2008), yaitu :

1. Prinsip relevansi; secara internal bahwa kurikulum memiliki relevansi di antara komponen-komponen kurikulum (tujuan, bahan, strategi, organisasi dan evaluasi). Sedangkan secara eksternal bahwa komponen-komponen tersebut memiliki relevansi dengan tuntutan ilmu pengetahuan dan teknologi (relevansi epistomologis), tuntutan dan potensi peserta didik (relevansi psikologis) serta tuntutan dan kebutuhan perkembangan masyarakat (relevansi sosilogis).
2. Prinsip fleksibilitas; dalam pengembangan kurikulum mengusahakan agar yang dihasilkan memiliki sifat luwes, lentur dan fleksibel dalam pelaksanaannya, memungkinkan terjadinya penyesuaianpenyesuaian berdasarkan situasi dan kondisi tempat dan waktu yang selalu berkembang, serta kemampuan dan latar bekang peserta didik.

3. Prinsip kontinuitas; yakni adanya kesinambungandalam kurikulum, baik secara vertikal, maupun secara horizontal. Pengalaman-pengalaman belajar yang disediakan kurikulum harus memperhatikan kesinambungan, baik yang di dalam tingkat kelas, antar jenjang pendidikan, maupun antara jenjang pendidikan dengan jenis pekerjaan.

4. Prinsip efisiensi; yakni mengusahakan agar dalam pengembangan kurikulum dapat mendayagunakan waktu, biaya, dan sumbersumber lain yang ada secara optimal, cermat dan tepat sehingga hasilnya memadai.

5. Prinsip efektivitas; yakni mengusahakan agar kegiatan pengembangan kurikulum mencapai tujuan tanpa kegiatan yang mubazir, baik secara kualitas maupun kuantitas.

Merujuk pada Supriatna (2012: 115), kurikulum yang seharusnya dijadikan acuan dalam mengembangkan inovasi pembelajaran dan haruslah merupakan sebuah konsep liberation yang wajib dimiliki setiap individu. Kurikulum tersebut harus terbebas dari kepentingan-kepentingan dari pihak yang sedang berkuasa, atau disebut sebagai relasi kuasa. Kurikulum yang ada selama ini dianggap sangat terbelenggu oleh relasi kuasa ini, sehingga tidak memberikan otonomi yang luas kepada guru dan sekolah untuk mengembangkannya sesuai dengan konteks daerah setempat. Hal tersebut terlihat dari sejumlah ketetapan, peraturan pemerintah atau menteri yang "wajib diikuti" seperti adanya oleh guru dan sekolah.

Jika kurikulum pendidikan di Indonesia sudah mampu terbebas dari relasi kuasa tersebut, boleh jadi mampu mewujudkan visi, misi dan strategi pembangunan pendidikan nasional yang telah ditetapkan. Merujuk pada Permendiknas No.41 tahun 2007 tentang 
Standar Proses, visi pendidikan nasional adalah terwujudnya sistem pendidikan sebagai pranata sosial yang kuat dan berwibawa untuk memberdayakan semua warga negara Indonesia berkembang menjadi manusia yang berkualitas sehingga mampu dan proaktif menjawab tantangan zaman yang selalu berubah. Mengingat kebhinekaan budaya, keragaman latar belakang dan karakteristik peserta didik, serta tuntutan untuk menghasilkan lulusan yang bermutu, proses pembelajaran untuk setiap mata pelajaran harus fleksibel, bervariasi, dan memenuhi standar. Proses pembelajaran pada setiap satuan pendidikan dasar dan menengah harus interaktif, inspiratif, menyenangkan, menantang, dan memotivasi peserta didik untuk berpartisipasi aktif, serta memberikan ruang yang cukup bagi prakarsa, kreativitas, dan kemandirian sesuai dengan bakat, minat, dan perkembangan fisik serta psikologis peserta didik.
Lebih jauh lagi, jika inovasi pendidikan dan pembelajaran di Indonesia mampu dijalankan dengan baik, maka tidak hanya sumber daya manusia yang beradab yang akan terbentuk, melainkan juga akan tercapainya visi misi pendidikan dan kebudayaan. Merujuk pada Renstra Kemdikbud 2010-2014 (2010: 37), dalam rangka mewujudkan cita-cita mencerdaskan kehidupan bangsa dan sejalan dengan visi pendidikan dan kebudayaan, Kemdikbud mempunyai visi 2025 untuk menghasilkan Insan Indonesia Cerdas dan Kompetitif (Insan Kamil/Insan Paripurna). Yang dimaksud dengan insan Indonesia cerdas adalah insan yang cerdas komprehensif, yaitu cerdas spiritual, cerdas emosional, cerdas sosial, cerdas intelektual, dan cerdas kinestetis. Lebih lengkap temtang makna dari insan Indonesia yang cerdas tersebut dapat dilihat dalam tabel berikut ini:

Tabel 1.Makna Insan Indonesia Cerdas dan Kompetitif

\begin{tabular}{|c|c|c|}
\hline & Makna Insan Indonesia Cerdas & \multirow{3}{*}{\begin{tabular}{l}
\multicolumn{1}{c}{$\begin{array}{c}\text { Makna Insan } \\
\text { Indonesia } \\
\text { Kompetitif }\end{array}$} \\
- Berkepribadian unggul \\
dan gandrung akan \\
keunggulan \\
- Bersemangat juang \\
tinggi \\
- Jujur \\
- Mandiri \\
- Pantang menyerah \\
- Pembangun dan \\
pembina jejaring \\
- Bersahabat dengan \\
perubahan \\
- Inovatif dan menjadi \\
agen perubahan \\
- Produktif
\end{tabular}} \\
\hline $\begin{array}{l}\text { Cerdas } \\
\text { spiritual }\end{array}$ & $\begin{array}{l}\text { - Beraktualisasi diri melalui olah hati/kalbu untuk } \\
\text { menumbuhkan dan memperkuat keimanan, ketakwaan } \\
\text { dan akhlak mulia termasuk budi pekerti luhur dan } \\
\text { kepribadian unggul. }\end{array}$ & \\
\hline $\begin{array}{l}\text { Cerdas } \\
\text { emosional } \\
\text { dan sosial }\end{array}$ & $\begin{array}{l}\text { - Beraktualisasi diri melalui olah rasa untuk } \\
\text { meningkatkan sensitivitas dan apresiativitas akan } \\
\text { kehalusan dan keindahan seni, nilai-nilai budaya, serta } \\
\text { kompetensi untuk mengekspresikannya. } \\
\text { - Beraktualisasi diri melalui interaksi sosial yang (a) } \\
\text { membina dan memupuk hubungan timbal balik; (b) } \\
\text { demokratis; (c) empatik dan simpatik; (d) menjunjung } \\
\text { tinggi hak asasi manusia; (e) ceria dan percaya diri; (f) } \\
\text { menghargai kebhinekaan dalam bermasyarakat dan } \\
\text { bernegara; (g) berwawasan kebangsaan dengan } \\
\text { kesadaran akan hak dan kewajiban warga negara. }\end{array}$ & \\
\hline $\begin{array}{l}\text { Cerdas } \\
\text { intelektual }\end{array}$ & $\begin{array}{l}\text { - Beraktualisasi diri melalui olah pikir untuk } \\
\text { memperoleh kompetensi dan kemandirian dalam ilmu } \\
\text { pengetahuan dan teknologi. } \\
\text { - Aktualisasi insan intelektual yang kritis, kreatif, } \\
\text { inovatif, dan imajinatif. }\end{array}$ & $\begin{array}{l}\text { - Sadar mutu } \\
\text { - Berorientasi global } \\
\text { - Pembelajaran } \\
\text { sepanjang hayat } \\
\text { - Menjadi rahmat bagi }\end{array}$ \\
\hline $\begin{array}{l}\text { Cerdas } \\
\text { kinestetis }\end{array}$ & $\begin{array}{l}\text { - Beraktualisasi diri melalui olah raga untuk } \\
\text { mewujudkan insan yang sehat, bugar, berdayatahan, } \\
\text { sigap, terampil, dan trengginas. } \\
\text { - Aktualisasi insan adiraga. }\end{array}$ & semesta alam \\
\hline
\end{tabular}




\section{KESIMPULAN}

Pendidikan IPS mengintegrasikan antara pendidikan dan kebudayaan, yakni keseluruhan gagasan, perilaku, dan hasil karya manusia yang dikembangkan melalui proses pembelajaran. Integrasi tersebut dapat berfungsi sebagai pedoman untuk kehidupan bermasyarakat, berbangsa, dan bernegara. Pada akhirnya, keseluruhan proses dan hasil interaksi sistemik dari pendidikan dan kebudayaan, baik lingkup lokal maupun global, yang terkait satu sama lain, diharapkan akan mendorong ke arah kemajuan peradaban bangsa.

Pergeseran paradigma pembangunan pada abad ke-21 yang berbasis pada kekayaan peradaban, telah menuntut pula pada adanya inovasi pendidikan dan pembelajaran di Indonesia, termasuk Pendidikan IPS. Hal tersebut merupakan bentuk respon yang diperlukan untuk menciptakan sumber daya manusia Indonesia yang beradab. yakni berpendidikan (berpengetahuan dan berketerampilan) dan berbudaya (berkarakter kuat). Jika pendidikan mampu membentuk sumber daya manusia Indonesia yang beradab, maka diharapkan proses pembangunan dapat terlaksana sesuai dengan tujuan nasional. Keharusan inovasi dalam pendidikan dan pembelajaran tersebut juga merupakan sebuah upaya untuk beradaptasi dengan perubahan yang terjadi pada abad ke-21.

\section{DAFTAR PUSTAKA}

Balitbang Pusat Kurikulum dan Perbukuan. (2011). Panduan Pelaksanaan Pendidikan Karakter. Jakarta : Kemdiknas

Banks, J.A. (1990). Teaching Strategies for the Social Studies: Inquiry, Valuing, and Decision Making. New York: Longman.

Brownhill, Robert, dan Smart, Patricia. (1989). Political Education. London: Routledge.

Griffin, P., Care, E., \& McGaw, B. (2012). The Changing Role of Education and Schools. Dalam Griffin, P., Care, E., \& McGaw (2012). (Editor). Assessment and Teaching of $21^{\text {st }}$ Century Skills. New York : Springer.

Kementrian Pendidikan dan Kebudayaan (2010). Renstra Kemdikbud 2010-2014. Jakarta : Kemdikbud.
Maftuh, Bunyamin. (2010). Memperkuat Peran IPS dalam Membelajarkan Keterampilan Sosial dan Resolusi Konflik. Pidato Pengukuhan Jabatan Guru Besar dalam bidang Pendidikan Ilmu Pengetahuan Sosial Pada FPIPS UPI. 28 Pebruari 2010.

McKinnon, Christine. (1999). Character, Virtue Theories and the Vices. Canada: Broadview Press.

Mutakin, Awan. (1998) Model Pembelajaran IPS. Jakarta : P3MTK-Ditjen Dikti.

NCSS. (1994). Curriculum Standards for Social Studies. Washington DC :NCSS.

Permendiknas no. 22 tahun 2006 tentang Standar Isi Mata Pelajaran

Permendiknas No.41 tahun 2007 tentang Standar Proses.

Sapriya. (2009). Pendidikan IPS : Konsep dan Pembelajaran. Bandung: Remaja Rosadakarya.

Somantri, Nu'man. (2001). Menggagas Pembaharuan Pendidikan IPS. Dedi Supriadi \& Rohmat Mulyana (ed). Bandung : PPS-FPIPS UPI dan PT. Remaja Rosda Karya.

Sudrajat, Akhmad. (2008). Prinsip Pengembangan Kurikulum. Tersedia: http://akhmadsudrajat.wordpress.com/200 8/01/31/prinsip-pengembangan kurikulum/ [6 Pebruari 2014].

Sumaatmadja, Nursid. (2001). Metodologi Pengajaran Ilmu Pengetahuan Sosial (IPS). Bandung: Alumni.

Supriatna, Nana (2012). Pandangan Postmodernisme dalam Mengembangkan Inovasi Pembelajaran IPS. Dalam Suryadi, K., Malilah, E. (2012). (Editor). Inovasi Pembelajaran IPS. Bandung : Rizqi Press.

Tilaar. H.A.R., dan Ace Suryadi. (1994). Analisis Kebijakan Pendidikan Suatu Pengantar. Cet. II. Bandung: Remaja Rosda Karya.

Trilling, Bernie. and Fadel, Charles. (2009). 21st Century Skills Learning for Life in Our Times. San Francisco: Jossey-Bass.

Undang-Undang No 20 Tahun 2003 tentang Sistem Pendidikan Nasional

Zuchdi, D. (2008). Humanisasi Pendidikan: Menemukan Kembali Pendidikan yang Manusiawi. Jakarta: Bumi Aksara 
